\title{
Antecedents of Visiting Decisions on Artificial Travel Destinations: Millennial Generation Perspectives
}

\author{
Sukaris \\ Aries Candra Setyawan \\ Dept of Management, Faculty of Economics and Business, Universitas Muhammadiyah \\ Gresik \\ sukaris21@umg.ac.id
}

\begin{abstract}
ABSTRAK
Tujuan dari penelitian ini adalah untuk mengetahui pengaruh motivasi wisatawan, informasi secara elektonik dari mulut ke mulut (e-WOM) dan citra tujuan wisata pada keputusan untuk mengunjungi Istana Gunung Mas di Lamongan. Sampel menggunakan metode non probabilitas sampling dengan purposive sampling atau prosedur pengambilan sampel acak dengan memilih 106 pengunjung. Teknik analisis data menggunakan regresi linier berganda. Hasil analisis regresi linier berganda membuktikan bahwa motivasi wisata dan citra destinasi terbukti tidak berpengaruh signifikan secara parsial terhadap keputusan menuju Istana Gunung Mas di Lamongan, sedangkan elektronik dari mulut ke mulut terbukti memiliki pengaruh signifikan parsial terhadap keputusan untuk mengunjungi Istana Gunung Mas di Lamongan
\end{abstract}

Kata Kunci: Wisatawan, destination, citra, Motivasi. E-WOM

\section{ABSTRACT}

The purpose of this study was to determine the effect of tourist motivation, electronic word of mouth and destination image on the decision to visit the Gunung Mas Palace in Lamongan. The sample uses non probability sampling method with a purposive sampling or random sampling procedure by selecting 106 visitors. The data analysis technique uses multiple linear regression. The results of multiple linear regression analysis prove that tourist motivation and destination image proved not to have a significant effect partially on decisions leading to Gunung Mas Palace in Lamongan, while electronic word of mouth proved to have a partially significant influence on the decision to visit the Gunung Mas Palace in Lamongan

Keywords: Tourist, destination, image, motivation. E-WOM

\section{INTRODUCTION}

Tourism is one of the important sectors for Indonesia. The component of natural and cultural wealth is an important part of Indonesian tourism. Abundant wealth makes Indonesian tourism popular with domestic and foreign visitors. This has led to intense competition between the tourism industries which requires managers to increase competitiveness by innovating one of them through the development of marketing strategies from traditional marketing to modern marketing strategies.
The right strategy can be used as a shield by the tourism industry in readiness to face competition both in the present and in the future to achieve the goals and sustainability of the tourism industry. Visitors are things to consider in the tourism sector. At this time the way of viewing visitors has changed. In the past visitors were interpreted as objects to earn income, while now visitors are interpreted as a determinant of the subject of industrial success. .

Public interest in natural tourism triggered the development of a natural tourism site in East Java, including in Lamongan Regency. 
Many tourism potentials in Lamongan Regency are not inferior to the Regency / Kotalainnya in East Java. Some of them are nature tourism, beach tourism and artificial tourism in the southern region of Lamongan regency, including Gondang Reservoir and Gondang Outboundond Educative Tourism located in Sugio District, Telogo Sendang and Maharani Zoo and Goa located in Paciran District and Bahari Lamongan Tourism which is the Leading Destination of Lamongan Regency. In addition to natural attractions, there are many attractions such as pilgrimage tours, such as eating Sunan Drajat.

The Geographical Location of Lamongan Regency, which is on the north coast of East Java Province, has made Lamongan Regency a part of the Surabaya metropilitan city area, the Kertosusila Gate. Making Lamongan Regency has a very strategic position in developing the world of tourism, because the location of Lamongan Regency is between the major cities in East Java, namely, the North side borders the Java Sea, the East borders with Gresik Regency, the South borders with Jombang Regency and Mojokerto Regency, in the west bordering Bojonegoro and Tuban Regencies.

One of the attractions in Lamongan Regency is Gunung Mas Palace. Gunung Mas Palace is an artificial natural tourist attraction that is relatively new in Lamongan Regency. Gunung Mas Palace itself carries the concept of a Chinese house, where the object offered is in the form of a Chinese house surrounded by beautiful cliffs, which are its flagship destination, very suitable for use in places to take pictures, and vacation with family.

The phenomenon of millennial generation also helps to promote the tourism of Gunung Mas Palace. By 2020, the number of millennials is estimated to be the largest in Indonesia. Millennial generation or native digital generation, the generation that grows in an alldigital environment. One of the lifestyle standards that is often done in terms of traveling. Of course this is a separate opportunity for the world of tourism, including
Lamongan Regency. A small city that is growing in identity as the center of the economy and lifestyle in East Java. Digital native is equipped with many technologies to make life easier, including when choosing tourist sites. The power of recommendations is an alternative. Through various social media, Facebook, Instagram, path, Twitter, and other online media Word of Mouth (WOM) can be delivered. Word of mouth communication provides good and bad for a tourist place, where the good and bad things will have an impact on the decision to visit.

Many factors motivate people to travel because most people want to find a new place to unwind because of busy activities. The level of popularity of the Gunung Mas Palace which is still minimal in the ears of the people required steps to popularize the Gunung Mas Palace one way through Electronic Word Of Mouth. The facts obtained in the field are still few people who talk about the Gunung Mas Palace and social media are also still a little that discusses the Gunung Mas Palace and the public perception of the Gumung Mas Palace tour is also not quite so good because this tour is classified as a new tour. According to Indriyani, (2018), the image can be interpreted as a public perception of the identity of a company or association according to research. In addition, according to Kotler and Keller (2009: 406) image is a number of beliefs, ideas and impressions held by someone about an object. While the image contained in a tourist destination is known as a destination image (destination image). Some previous research in the field of marketing, especially related to visiting decisions and purchasing decisions shows the importance of consumer motivation (Keliwar \& Nurcahyo, 2015; Kusuma \& Suryasih 2016; Fitroh et al 2017), electronic word of mouth (Sukaris, 2013; 2018; Humaira \& Wibowo, 2016; Hasan \& Setiyaningtiyas 2015), destination image (Ahmad, 2018; Indriyana, 2018). However, destination studies related to millennial generation and motivation to visit artificial tours have not been done much 
even though this tour in Indonesia is being developed. So based on this description, this article aims to determine the effect of motivation to travel, electronic word of mouth and destination image on the decision to visit the destination of the millennial generation perspective.

\section{LITERATURE REVIEW}

\section{Tourism}

Motivation Motivation is very basic in the study of tourists and tourism, because motivation is a trigger from travel, although this motivation is often not fully realized by the tourists themselves (Malik, 2016) Motivation according to Josiam and Frazer (in Rohmanah, 2014) consists of 4 factors namely novelty seeking, stress busting / fun, achievement, family oriented / education.

1. Novelty Seeking

Novelty seeking is the motivation to look for something new, feel new experiences and enjoy new tourist attractions.

2. Stess busting / fun

Stress busting / fun is a tourist motivation for relieving boredom or stress from daily routine.

3. Achievement

Achievement is the motivation of visiting tourism for prestige reasons (prestige). Tourists have the motivation to visit tourist attractions that have not been addressed by friends, relatives or relatives.

4. Family oriented / education

Family oriented / education is tourism motivation to gather and travel with family.

\section{Destination}

Image Image or image can be interpreted as a public perception of the identity of a company or association according to Indriyani's research, (2018). In addition, according to Kotler and Keller (2009: 406) image is a number of beliefs, ideas and impressions held by someone about an object. While the image contained in a tourist destination is known as a destination image (destination image).
Lawson and Bovy in Lopes (2011: 307) define that "destination image is a concept as the expression of all objectives, knowledge, prejudices, imagination and emotional thoughts of an individual or group about a particular location", which means that destination images are objective knowledge , prejudice, imagination and emotional thoughts of individuals and groups towards a particular location.

According to Indriyani, (2018) that destination image is a belief and impression held by someone about a place. Then explained also by Tasci and Kozak (2006: 304), destination images are individual perceptions of destination characteristics that can be influenced by promotional information, mass media and many other factors. Likewise, according to Coshall (2002: 89) which states that the destination image is a general impression of a tourist towards a tourist destination.

The image of a destination is an important part of being sold to stakeholders including tourists. Fakeye and Crompton in Chen (2007: 1116) state that destination images are images, thoughts, beliefs, feelings and perceptions of a destination. In addition, according to Echtner and Ritchie (2003: 35), destination images are perceptions of potential tourists towards a destination. Still according to Echtner and Ritchie (2003: 35), destination images are perceptions of complex combinations of various products and related attributes.

\section{Electronic Word of Month}

Electronic word of mouth is a positive or negative statement made by potential customers or former customers about a product or company, which is intended for many people or institutions via the internet (Hennig-Thurau et.al., 2004: 39). This opinion is in accordance with the opinion of Kevin et.al., in Hasan (2015: 227), electronic word of mouth is a positive or negative statement by potential, actual or former consumers about a product or company 
and disseminated to other people or other companies via the internet .

Charo et.al., (2015: 41) that the form of online information and knowledge exchange on social media is known as electronic word of mouth (e-WOM). In addition, according to Jalilvand and Samiei (2012: 2), increased use of the internet and social networking is also an important matter where Word of Mouth is not only done individually but can be in any form, including the internet called the Electronic Word of Mouth (e-WOM). Therefore, it can be said that electronic word of mouth is done through social media and the internet. The effectiveness of electronic word of mouth is more effective compared to word of mouth communication in the offline world, because of greater accessibility and high reach.

Goldsmith and Horowitz (2006: 3), revealed that in the online world, there are various ways in which consumers can exchange information. Internet users can do electronic word of mouth through various online channels, including blogs, microblogs, e-mails, consumer review sites, forums, virtual consumer communities and social networking sites.

The Word of Mouth Association (WOMMA) defines simply word of mouth marketing as someone's act of sharing interesting information with others. Consumers tend to accept suggestions from relatives, friends and family because of the high credibility between them when talking about the products consumed.

Based on the above opinion it can be concluded that electronic word of mouth is a form of marketing by expressing positive or negative statements that tend to be included in the communication section delivered through social media to provide information, promote, recommend a product or service.

\section{Visiting Decision}

In relation to the world of tourism, purchasing decisions are assumed to be visiting decisions so theories about purchasing decisions are also used in visiting decisions.
Purchasing decision is an integration process that combines knowledge to evaluate two or more alternative behaviors and choose one of them (Peter and Olson, 2000: 162). According to Swastha and Handoko (2000: 102), purchasing decisions taken by buyers are a collection of a number of decisions. Each purchasing decision has a structure of seven components, including decisions about product types, decisions about product form, decisions about brands, decisions about sales, decisions about product quantities, decisions about time of purchase and decisions about how to purchase.

The decision to visit is a stage where the consumer has a choice and is ready to make a purchase or exchange between money and a promise to pay with ownership rights or use of an item or service, (Kotler, 2005: 202). In addition, Sumarwan (2011: 357), states the decision is an action of two or more alternative choices. All aspects of affection and cognition are involved in decision making. The key process in consumer decision making is the integration process in which knowledge is combined to evaluate two or more alternative behaviors and then choose one. Therefore, Kotler and Armstrong (2001: 226), states that the purchase decision is the stage in the buyer decision process where consumers actually buy.

According to Private and Handoko (2000: 15), purchasing decisions are an approach to solving problems in human activities to buy goods or services in meeting their wants and needs consisting of the introduction of needs and wants, information seeking, evaluation of alternative purchasing, purchasing decisions, and behavior after purchase.

From the understanding of the purchase decision above, it can be concluded that the decision to visit is a person's buying behavior in determining a choice of tourist attractions to achieve satisfaction according to the needs and desires of consumers which includes the introduction of problems, information search, evaluation of alternative purchasing, purchasing decisions and behavior after purchase. 
Sumarwan (2011: 358-359), suggests 4 kinds of perspectives from the human model (model of man). The human model in question is a model of decision behavior of an individual based on 4 perspectives, namely:

1. Economic human is a model that describes humans who make decisions rationally. Economic people try to make decisions that provide maximum satisfaction. Decisions are based on economic considerations, such as price and quantity of goods

2. Passive humans are models that portray humans as selfish individuals and accept various promotions offered by marketers. Passive human models are considered unrealistic. Consumers are described as irrational and impulsive buyers.

3. Human cognitive is a model that describes humans as individuals who think to solve problems. Cognitive models describe consumers as an information processing system. Information processing will lead to the formation of preferences and subsequently to the desire to buy.

Emotional people are consumers as individuals who have deep feelings and emotions that influence the purchase or possession of certain goods. Consumers who make emotional purchasing decisions, very little effort is made to find information before buying.

\section{Millennial}

Generation Millennial generation is a designation intended for population groups born in 1982-2004 (Moore, 2012). The term Millennial Generation was originally used in the United States of America which was then used by other countries in the world. Based on 2015 BPS data, the number of millennials in Indonesia has reached 84 million people or 50 percent of the population of productive age (Kompas.com, 2017). Millennial generation is a generation that has a high level of confidence in purchasing decision making (Henry and Taylor, 2009). The millennial generation also has a high income level and has begun to use credit cards in making purchases and often has the task of spending for families (Neuborne in Henrie and Taylor, 2009). The millennial generation is an early adopter of technological development and innovation (Kumar and Lim in Tan and Lau, 2016). Based on research conducted by Goldman Sachs in fourhooks.com (2016) it was found that the millennial generation was born in the midst of technological change, globalization and economic turmoil in which it led to the creation of a set of different behaviors in the millennial generation including behavior in shopping

\section{Hypothesis}

Based on the theoretical basis and framework of thought previously explained, the hypotheses in this study are:

H1: Tourism Motivation has a positive and significant impact on the decision of the millineal generation to visit Gunung Mas Palace

$\mathrm{H} 2$ : Electronic word of mouth has a positive and significant effect on the decision of the millineal generation to visit the Gunung Palace Mas

H3: The destination image has a positive and significant impact on the decision of the millennial generation to visit Gunung Mas Palace

\section{METHODE}

The research approach used in this study is an associative method because there are variables in the study of the relationship and its purpose to present a structured, factual, and accurate picture of the factors and the relationship of the variables examined, according to Sugiyono (2015, associative research is research that aims to determine the relationship of two or more variables.In this study it will be able to build a theory that can serve to explain, predict, and control a symptom.

The population referred to in this study is miillenial generation tourists, that is, the age 
between those included in the millineal generation. the sample size in this study was 106 respondents and fulfilled the requirements and to calculate the determination of the number of samples using the Slovin formula

In this study, the type of data used by researchers is Primary Data, namely questionnaires as research instruments, in order to produce quantitative data, Likert scale as a measurement scale. The data analysis techniques used in this study are the validity test, reliability test, classic assumption test, multiple linear regression equations, coefficient of determination and $t$ test

\section{RESULTS AND DISCUSSION}

In analyzing the data of this study used inferential methods to test the research objectives. In order to determine the effect and significance level of the independent variables on the dependent variable with regression analysis. The regression formula model is divided into two equations $\mathrm{Y}=\mathrm{bo}+\mathrm{b} 1 \mathrm{X} 1+$ $\mathrm{b} 2 \mathrm{X} 2+\mathrm{b} 2 \mathrm{X} 2+\mathrm{e}$. In answering the research objectives, data analysis is carried out based on these equations. Prior to the regression analysis, a bias test (econometric test with model results has fulfilled the assumptions in the econometrics test has been carried out, as well as research instrument testing through validity and reliability testing with the results of all indicators and research variables fulfilling the requirements for regression testing because the resulting value is greater than the criteria required.In the test of the validity of the instruments all variables obtained $r$ count $>r$ table 0.1891. So all the statements of the independent and dependent variables are proven to be valid because all statements of the independent and dependent variables are greater from 0.1891. In the reliability test that each variable Cronbach Alpha value is greater than 0.6 , so it can be concluded that the measuring instrument used in this study is reliable because all cronbach Alpha value variables are greater than 0.6
The results of regression analysis $\mathrm{Y}=$ $1.171+0.355 X \_1-0.005 X \_2+0.461 X \_3+e$, a constant value of 1.171 shows that if the motivation of traveling (X1), electronic word of mouth (X2) and destination image (X3) are 0 , then the decision to visit ( $\mathrm{Y}$ ) amounting to 1,171. then without or before the tour motivation variable (X1), electronic word of mouth (X2) and destination image (X3) worth in the agency, the amount of visiting decision $(\mathrm{Y})$ is 1,171 . The results of tourism motivation variables have a positive direction toward visiting decisions, electronic word of mouth variables have a negative direction toward visiting decisions and destination image variables have a positive direction toward visiting decisions.

The results of the coefficient of determination (R2) indicate the ability of the model to explain variations independent variable. "The coefficient of determination (R2) with a value of .0530 or 53 percent of visiting decisions can be explained by variables in the model, while the remaining $47 \%$ can be explained by other factors outside the variable.

Hypothesis testing, explained as follows:

1. Known significance value for the effect of $\mathrm{X} 1$ on $\mathrm{Y}$ is $0,000<0.05$ then $\mathrm{H} 0$ is accepted and $\mathrm{Ha}$ is rejected, which means that tourism motivation (X1) has a significant effect on the visiting decision variable (Y).

2. It is known that the significance value for the effect of $\mathrm{X} 2$ on $\mathrm{Y}$ is $0.935>0.05$ then $\mathrm{HO}$ is accepted and Ha is rejected, which means that the electronic word of mouth (X2) has no significant effect on the decision to visit $(\mathrm{Y})$.

3. Given the significance value for the effect (X3) on (Y) is $0.03<0.05$ then $\mathrm{H} 0$ is rejected and $\mathrm{Ha}$ is accepted, which means that the destination image (X3) has a significant influence on the visiting decision $(\mathrm{Y})$

The influence of tourism motivation on millineal generation visiting decisions, the results of the first hypothesis testing showed the 
value for the tourism motivation variable of $0,000<0.05$, which means that tourism motivation significantly influenced the millineal generation decision decision variable. Significant results indicate an increase or decrease. The decision to visit is influenced by the motivation of millineal tourism. With tourist motivation, visitors can be an impetus to feel new experiences, reduce stress and can spend time with family. This significant result shows that tourism motivation is able to be a determining factor in the decision to visit for the millineal generation. The results of this study are consistent with research conducted by Fitroh (2017) which states that tourism motivation has a significant effect on visiting decisions. With this it shows that the stronger the motivation of tourist tourism will determine the decision of tourists visiting.

The effect of electronic word of mouth on millineal generation visitation decisions. The results of the second hypothesis testing show the significance value for the visiting decision variable as much as $0.935>0.05$. Then the Electronic Word of Mouth (X2) variable proved to have no effect on the decision to visit. The results show that electronic word of mouth has no influence on millennial generation visiting decisions. Negative statements posted by visitors on social media / Instagram cause visitors to pay little attention to visiting tourist destinations. Kevin et.al (2015: 41) states that positive or negative statements by potential, actual and former consumers about a product or company and disseminated to other people or other companies through the internet. The results that have no effect show that electronic word of mouth is not able to be a determining factor in visiting decisions. The results of this study contradict the research conducted by Ardiyanto (2017) who said that electronic word of mouth had a significant and dominant positive effect on visiting decisions. This means that electronic word of mouth is the most important thing in determining a visit decision so that the better the electronic word of mouth and in accordance with the perception of visitors will determine the decision to visit tourists.

The effect of destination image on millineal generation visiting decisions. The results of the third hypothesis testing show the significance value for the Location variable of $0.003<0.05$. Then the destination image variable proved to have a significant effect on a visiting decision. Significant results show that the image of a good destination can be a reference for a tourist to determine his visit. According to Indriyani's research (2018), destination destinations are beliefs and impressions held by a person about a place. This significant result shows that the destination image factor is able to be the determining factor for a visiting decision. These results of this study are in accordance with research conducted by Priyanto (2016) who said that the image of the destination has a significant effect on the decision of visiting. A good destination image can become a tourist destination as an alternative destination for tourists.

\section{CONCLUSION}

Based on the results of data analysis and interpretation of the results, the conclusion of the influence of travel motivation, electronic word of mouth and destination image of the decision to visit at the destination of the millennial generation perspective is that tourism motivation has a positive influence and direction on the decision to visit, Electronic word of mouth has no effect and the direction is negative towards the decision to visit, and the image of the destination is influential and the direction is positive towards the decision to visit the millineal generation at the tourist destination. Implications for managerial aspects of tourist destinations must increase tourist confidence by providing information about excellence and beauty through media that are becoming or favored by millennials given the large population of this generation and the implication for future research is that the results of this study can be used as a reference to 
multiply the number of variables or look for phenomena in the field by looking at things that can affect visiting decisions. For example tourist attractions, hospitality, comfort and others or adjust the target market segment.

\section{REFERENCES}

Ahmad, A. B. (2018). Citra Destinasi Dan Pengaruhnya Terhadap Intensi Untuk Berkunjung Kembali Di Sulawesi Selatan Sebagai Destinasi Pariwisata. Sosiohumaniora, 20(3), 207-214.

Ariyanto. (2005). Ekonomi Pariwisata. Jakarta: Penerbit Rineka Cipta

Charo, N., Sharma, P., Shaikh, S., Haseeb, A., dan Sufya, M. Z. (2015). Determining the Impact of E-wom on Brand Image and Purchase Intention through Adoption of Online Opinions. 3(1).

Chen, C and Tsai, D. (2007). Manajemen Pemasaran Jasa. Kelompok Gramedia: indeks.

Cheung, C. M \& Lee, M. K. (2012). What drives consumers to spread electronic word of mouth in online consumeropinion platforms. Decision support systems, 53(1), 218-225.f Interactive Advertising, Vol. 6 No. 2,pp. 1-6.

Deksono, Favian Rachmadi. (2017). Pengaruh Motivasi Wisata dan Electronic Word Of Mouth Terhadap Minat Berkunjung ke Daya Tarik Goa Pindul. Skripsi Universitas Sanata Dharma. Yogyakarta.

Dewi. Indriyani Ratna. (2018). Pengaruh Electronic Word Of Mouth, Citra Destinasi Dan Fasilitas Wisata Terhadap Keputusan Berkunjung Yang Dimediasi Oleh Respon Emosional (Studi pada Pengunjung Wahana Air Lampung Walk Bandar Lampung). Skripsi Universitas Lampung Bandar Lampung.

Echtner, Charlotte M dan J.R. Brent Ritchie. (2003). The meaning and measurement of destination image.
The journal of tourism studies vol.14, no. 1 may 03. Canada

Fitroh, S. K. A., Hamid, D., \& Hakim, L. (2017). Pengaruh Atraksi Wisata dan Motivasi Wisatawan Terhadap Keputusan Berkunjung (Survei pada Pengunjung Wisata Alam Kawah Ijen). Jurnal Administrasi Bisnis, 42(2), 18-25.

Ghozali, Imam. (2016). Aplikasi Analisis Multivariete Dengan Program IBM SPSS 23 (Edisi 8). Cetakan ke VIII. Semarang : Badan Penerbit Universitas Diponegoro.

Hailin, Qu., Kim, L.H., Im, H.H. (2011). "A model ofdestination branding: integreting the concepts of the branding and destination image", Tourism Management, Vol.32,pp. 465-475.

Hasan, A., \& Setiyaningtiyas, N. W. (2015). Pengaruh Electronic Word of Mouth pada Media Sosial Facebook terhadap Keputusan Berkunjung ke Desa Wisata Nglanggeran Gunungkidul. Jurnal Media Wisata: Wahana Informasi Pariwisata, 13(1).

Hennig-Thurau, Kevin Gwinner., Gianfranco Walsh., and Dwayne Gremler. (2004). Electronic Word of Mouth Via Consumer Opinion Platform : What Motivates Consumers To Articulate Themselves on The Internet ?.Journal of Interactive Marketing.38:52.

Humaira, A., \& Wibowo, L. A. (2016). Analisis Faktor Elektronik Word Of Mouth (EWOM) Dalam Mempengaruhi Keputusan Berkunjung Wisatawan. THE Journal: Tourism and Hospitality Essentials Journal, 6(2), 1049-1060.

Jalilvand, M. R and Samiei, N. (2012). The Effect of Electronic Word Of Mouth on Brand Image and Purchase Intention: An Empirical Study in The Automobile Industry in Iran". Marketing Intelligence \& Planning, Vol. 30 No. 4, pp. 460-476 
Keliwar, S., \& Nurcahyo, A. (2015). Motivasi dan Persepsi Pengunjung terhadap Obyek Wisata Desa Budaya Pampang di Samarinda. Jurnal Manajemen Resort dan Leisure, 12(2).

Kotler, Philip, dan Gary Armstrong. (2001). Prinsip-Prinsip Pemasaran. Edisi 12. Jakarta: Erlangga

Kotler, Philip, dan Gary Armstrong. (2004). Dasar-dasar pemasaran. Jakarta: PT Indeks

Kotler, Philip. (2005). Manajemen Pemasaran. Jilid I. Jakarta: PT.Indeks

Kusuma, I. G. A. R. D., \& Suryasih, I. A. 2016. Aktivitas Wisata Spiritual dan Motivasi Berwisata Di Daya Tarik Wisata Tanah Lot Kabupaten Tabanan. Jurnal Destinasi Pariwisata, 4(2), 118-122.

Malik. Moh. Ibram dan M. Kholid Marwadi. (2016). Penagrud City Branding "The Soul Of Madura dan terhadap Keputusan Berkunjung Ke Kabupaten Sumenep. Jurnal Administrasi Bisnis. Vol. 37. (Agustus) No. 1

Mcdaniel, Lamb dan Hair. (2001). Pemasaran Buku Satu. Jakarta: Salemba Empat

Mowen, John C dan Michael Minor. (2002), Perilaku Konsumen (Jilid 1), Edisi Kelima. Jakarta: Erlangga.

Oka A. Yoeti. (2008). Perencanaa dan pengembangan pariwisata. Jakarta: PT Pradnya Paramita

Peter, J Paul dan Jerry C Olson. (2000). Perilaku Konsumen dan Strategi Pemasaran. Edisi 4, jilid 1. Jakarta: Erlangga

Republik indonesia. (2009). Undang Undang No. 11 Tahun 2009 Tentang Kepariwisataan. Lembaran Negara republik indonesia tahun 2009. No 11 Sekertariat Negara: Jakarta

Sangadji, E.M dan Sopiah. (2013). Prilaku Konsumen: Pendekatan Praktis Disertai: Himpunan Jurnal Penelitian. Yogyakarta: Penerbit Andi
Sugiyono (2015). Metode Penelitian Kombinasi (Mix Methods). Bandung: Alfabeta

Sukaris, (2013) , Pengaruh Kualitas Layanan dan Nilai Pelanggan Terhadap Komunikasi Words of Mouth Positif melalui Kepuasan Pelanggan, Fakultas Ekonomi Umsida

Sukaris, S. (2019). Anteseden dan Konsekuensi Kepuasan Pelanggan dalam Konteks Word-Of-Mouth. Manajerial, 5(2), 24-31. doi:10.30587/manajerial.v5i2.825

Sumarwan, Ujang. (2011). Perilaku Konsumen. Bogor: Ghalia Indonesia.

Swastha, Basu, dan Hani Handoko. 2000. Manajemen Pemasaran Analisa Perilaku Konsumen. Yogyakarta: BPFE 